\title{
PRONOMINA PADA KARANGAN CERITA FANTASI SISWA
}

\author{
Hikmah Nur Azizah ${ }^{1}$, Hilda Hilaliyah ${ }^{2}$, Memmy Dwi Jayanti ${ }^{3}$ \\ E-mail: hikmazizah23@gmail.com, hilda.unindra@gmail.com,memmydj@gmail.com \\ Universitas Indraprasta PGRI, Jakarta Selatan
}

\begin{abstract}
Abstrak
Penelitian ini bertujuan untuk mengetahui dan menganalisis penggunaan pronomina pada karangan cerita fantasi siswa kelas VII SMP Harjamukti Depok. Metode yang digunakan adalah metode kualitatif sehingga bersifat deskriptif dan cenderung menggunakan analisis. Sumber data yang digunakan adalah karangan cerita fantasi siswa kelas VII SMP Harjamukti Depok sebagai acuan analisis serta berbagai buku dan artikel sebagai sumber data sekunder. Hasil penelitian ini menunjukkan bahwa penggunaan pronomina persona lebih dominan dibanding pronomina lainnya sebab pronomina ini berperan dalam mengembangkan karangan yang menarasikan manusia sebagai tokohnya.
\end{abstract}

Kata Kunci: Pronomina, cerita fantasi, karangan siswa.

\section{Pendahuluan}

Setiap kata yang digunakan untuk merujuk pada nomina lain disebut dengan pronomina atau kata ganti (Muslich, 2014: 78). Lebih jauh, Muslich menjelaskan bahwa rujukan yang ditunjuk suatu pronomina tidaklah tetap. Artinya, rujukan bergantung pada siapa orang pertama, orang kedua, serta topiknya. Berdasarkan pendapat tersebut, pronomina juga memerhatikan sebuah konteks yang membangun suatu teks atau ujaran yang di dalamnya mengandung pronomina. Pronomina memang tidak selalu mengganti suatu kata benda secara tekstual, tetapi juga kontekstual.

Pronomina atau kata ganti adalah kelas kata yang digunakan untuk menggantikan kata benda atau orang dalam sebuah kalimat. Pronomina digunakan agar penulisan kalimat menjadi lebih efisien tanpa ada pengulangan yang tidak perlu. Alwi, dkk. (2014: 255) berpendapat bahwa, "Jika ditinjau dari segi artinya, pronomina adalah kata yang dipakai untuk mengacu kepada nomina yang lain”. 
Lebih lanjut, Alwi, dkk. juga mengemukakan bahwa apabila ditinjau dari segi fungsi, pronomina dapat menggantikan posisi yang umumnya diduduki oleh nomina, seperti subjek, objek, dan dalam kalimat tertentu juga dapat menggantikan posisi predikat. Artinya, pronomina dapat menggantikan berbagai posisi selagi yang digantikannya adalah nomina.

Rahardi (2009: 59) menyatakan bahwa pronomina merupakan kata ganti yang menggantikan antesedennya. Lebih lanjut, Rahardi menyampaikan bahwa dengan menggunakan pronomina maka pengulangan nomina akan dapat dihindari. Pengulangan-pengulangan nomina yang terlalu sering akan membuat sebuah kalimat terdengar tidak efektif dan tidak enak dibaca. Oleh karena itu, penggunaan pronomina dapat membantu keefektifan kalimat.

Jenis-jenis pronomina menurut Chaer $(2015,87)$ terdiri atas 4 (empat), yaitu pronomina persona, pronomina demostrativa, pronomina introgativa, dan pronomina tidak tentu. Pronomina persona merupakan kata ganti yang digunakan untuk merujuk posisi orang dalam sebuah kalimat. Pronomina ini dapat dibagi menjadi pronomina persona pertama, kedua, dan ketiga. Pronomina persona pertama tunggal menggantikan penulis atau pembicara tunggal ( $a k u, s a y a)$, pronomina persona pertama jamak menggantikan penulis atau pembicara jamak (kami, kita). Pronomina persona kedua tunggal menggantikan orang yang diajak bicara tunggal (kamu, kau, Anda), sedangkan pronomina persona kedua jamak menggantikan orang yang diajak bicara jamak (kalian). Lalu, pronomina persona ketiga tunggal menggantikan orang yang dibicarakan tunggal (dia, ia) dan pronomina persona ketiga jamak menggantikan orang yang dibicarakan jamak (mereka).

Pronomina demostrativa merupakan kata ganti yang digunakan untuk merujuk posisi nomina yang ditunjuk dalam sebuah kalimat. Dapat dikatakan bahwa kata ganti penunjuk digunakan untuk menunjukkan sesuatu yang berupa benda atau suatu tempat tertentu. Pronomina demonstrativa dibagi menjadi pronomina penunjuk umum (ini, itu), pronomina penunjuk tempat (di sana, ke sana, dan lain-lain), dan pronomina penunjuk perihal (begini, begitu). 
Pronomina introgativa adalah pronomina yang digunakan untuk menanyakan sesuatu, baik itu orang, tempat, waktu, dan lain-lain. Pronomina penanya orang atau benda dapat menggunakan pronomina apa, siapa, dan yang mana. Pronomina penanya tempat dapat menggunakan pronomina di mana, dari mana, dan ke mana. Tedapat pula pronomina penanya waktu dapat menggunakan pronomina kapan. Selanjutnya, pronomina tidak tentu adalah kata ganti yang digunakan untuk merujuk kata benda yang tidak tentu. Kata ganti tidak tentu ini meliputi setiap orang, seseorang, salah seorang, siapa saja, suatu, sesuatu, salah satu, beberapa, sewaktu-waktu, dan masing-masing. Masing-masing pronomina sangat berperan dalam mengembangkan sebuah karangan.

Dalam penelitian ini, objek penelitian yang digunakan adalah karangan cerita fantasi siswa kelas VII SMP Harjamukti Depok. Alasan penulis memilih cerita fantasi sebagai objek karangan sebab salah satu ciri kebahasaan yang terdapat di dalamnya adalah pronomina atau kata ganti. Oleh karena itu, penelitian tentang pronomina atau kata ganti dalam cerita fantasi ini penting.

Cerita fantasi menurut Nurgiyantoro (2018: 295) ialah cerita yang menampilkan tokoh, alur, latar, tema, dan segala unsur-unsur di dalamnya yang diragukan kebenarannya, baik yang berkaitan dengan seluruh atau sebagian cerita. Ia juga menyatakan bahwa sebagian atau bagian-bagian tertentu dalam cerita fantasi merupakan hal-hal yang masuk akal dan logis, hanya saja dicampuradukkan dengan sesuatu yang masuk akal. Namun, keseluruhan pengembangan cerita tetap dikembangkan menggunakan aturan sebab-akibat dan kronologis sehingga dapat dipertanggungjawabkan secara intrinsik.

Semua mitos, legenda, cerita rakyat, fabel, dan cerita hantu pada hakikatnya adalah fantasi (Sarumpaet, 2009: 27). Lebih lanjut, Sarumpaet juga menyatakan bahwa cerita fantasi ialah cerita yang dapat dikatakan mustahil, seperti kisah tentang para dewa, pria dengan kekuatan super, makhluk ajaib, sapu berjalan, anak penyembuh, dan hal-hal yang secara logika tidak mungkin ada. Namun, di dalam cerita fantasi terdapat kesatuan cerita yang berdasarkan yang dapat dipercaya secara logika dan realitas dan mempunyai pesan moral yang 
tersembunyi di dalamnya. Sedikit berbeda dengan pendapat sebelumnya, Sarumpaet menekankan adanya pesan moral yang terdapat dalam sebuah cerita fantasi, bukan hanya kisah yang imajinatif.

Sejalan dengan pendapat Sarumpaet, Huck (Nurgiyantoro, 2018: 295) mengemukakan bahwa cerita fantasi ialah cerita yang memiliki makna lebih dari sekadar apa yang disajikan sebuah cerita. Hal ini berarti cerita fantasi menyembunyikan pesan moral yang dibungkus dengan hal-hal yang bersifat imajinatif dan khayal. Jadi, dapat dipahami bahwa cerita fantasi tidak hanya berfungsi sebagai hiburan, tetapi juga berisi pelajaran.

Adapun masalah yang akan dibahas dalam penelitian ini adalah bagaimana penggunaan pronomina pada karangan cerita fantasi siswa kelas VII SMP Harjamukti Depok. Adapun tujuan dari penelitian ini adalah untuk mengetahui jenis-jenis penggunaan pronomina pada karangan siswa tersebut. Selain mengetahui, penelitian ini juga akan menganalisis penggunaan pronomina dalam karangan siswa.

\section{Metode Penelitian}

Penelitian ini menggunakan metode kualitatif. Sebagaimana sifat dari penelitian kualitatif, yaitu mencari makna dari suatu fakta atau fenomena. Oleh karena itu, kesungguhan dan ketelitian seorang peneliti sangat diperlukan ketika melakukan suatu observasi di lapangan agar dapat menemukan kebenaran makna dari fakta atau fenomena tersebut.

Data dalam penelitian ini terdiri atas data primer dan sekunder. Data primer yang digunakan adalah karangan cerita fantasi yang ditulis oleh siswa kelas VII SMP Harjamukti Depok yang berupa kata maupun kalimat dalam bentuk ungkapan dan/atau dialog antartokoh yang termasuk ke dalam kategori pronomina.

Sementara itu, data sekunder dalam yang digunakan dalam penelitian ini adalah segala sumber yang berhubungan dengan permasalahan dalam objek tulisan. Hampir semua jenis bahan pustaka dikelompokkan ke dalam data sekunder, seperti buku, artikel, atau esai. Sumber data sekunder yang digunakan 
dalam penelitian ini adalah karya tulis ilmiah, buku pelajaran, dan artikel yang berkaitan dengan objek penelitian, yakni karangan cerita fantasi siswa kelas VII SMP Harjamukti Depok sebagai data primer.

Dalam penelitian ini menggunakan dua teknik, yaitu teknik pencatatan data dan teknik pemeriksaan keabsahan data.

\section{1) Teknik Pencatatan Data}

Teknik yang dilakukan penulis dalam menyajikan data adalah sebagai berikut.

a. Mendata seluruh pronomina yang ada dalam karangan cerita fantasi siswa kelas VII SMP Harjamukti.

b. Mengklasifikan data pronomina.

c. Menganalisis pronomina.

d. Menghitung tingkat persentase pronomina dalam tajuk rencana pada karangan cerita fantasi siswa kelas VII SMP Harjamukti.

e. Menafsirkan dan menyimpulkan hasil penelitian.

f. Membuat laporan hasil penelitian.

\section{2) Teknik Pemeriksaan Keabsahan Data}

Adapun dalam tahap ini menggunakan teknik triangulasi, yaitu teknik pengumpulan data dengan cara menggabungkan berbagai teknik pengumpulan data dan sumber yang telah ada (Sugiyono, 2016: 241). Dengan menggunakan teknik triangulasi, penulis mengumpulkan data dan menguji kredibilitas data sekaligus, yaitu dengan menggunakan berbagai teknik pengumpulan data dan berbagai sumber data.

\section{Hasil Penelitian dan Pembahasan}

Pada penelitian ini penulis menemukan 755 temuan. Berdasarkan data yang diperoleh, peneliti menemukan berbagai penggunaan pronomina persona, pronomina demonstrativa, pronomina introgativa, dan pronomina tidak tentu. Bentuk-bentuk pronomina tersebut penulis temukan dalam karangan cerita fantasi yang dibuat oleh siswa kelas VII SMP Harjamukti Depok. 
Berikut adalah tabel rekapitulasi penggunaan pronomina pada karangan cerita fantasi siswa kelas VII SMP Harjamukti Depok.

\section{Tabel 1}

Persentase Penggunaan Pronomina pada Karangan Cerita Fantasi Siswa Kelas VII SMP Harjamukti

\begin{tabular}{clcc}
\hline No. & \multicolumn{1}{c}{ Pronomina } & Jumlah & Persentase (\%) \\
\hline 1. & Pronomina persona & 517 & $68,48 \%$ \\
2. & Pronomina demonstrativa & 183 & $24,24 \%$ \\
3. & Pronomina introgativa & 26 & $3,44 \%$ \\
4 & Pronomina tidak tentu & 29 & $3,84 \%$ \\
\hline \multicolumn{2}{c}{ Jumlah } & $\mathbf{7 5 5}$ & $\mathbf{1 0 0 \%}$ \\
\hline
\end{tabular}

\section{1) Penggunaan Pronomina Persona}

Penggunaan pronomina persona pada karangan siswa ini merupakan jumlah temuan terbanyak, yakni 517 temuan dari total 755 temuan yang ada. Data pronomina tersebut terbagi menjadi 371 temuan pronomina persona pertama tunggal dan 50 temuan pronomina persona orang pertama jamak. Data pronomina persona kedua tunggal sebanyak 35 dan pronomina persona kedua jamak sebanyak 2. Selain itu, data pronomina persona ketiga tunggal sebanyak 16 temuan dan data pronomina persona ketiga jamak sebanyak 8 temuan.

Pronomina persona pertama merupakan pronomina yang mengacu kepada pembicara selaku orang pertama. Temuan pronomina persona pertama tunggal meliputi kata saya berjumlah 144 temuan, kata $a k u 137$ temuan, proklitik $k u$ - 4 temuan, dan enklitik - ku 86 sebanyak temuan. Selanjutnya, temuan pronomina persona pertama jamak terdiri atas kata kami sebanyak 32 temuan dan kata kita sebanyak 18 temuan.

Pronomina persona kedua merupakan pronomina yang mengacu kepada pendengar atau pihak yang diajak bicara selaku orang kedua. Temuan pronomina persona kedua tunggal meliputi kata kamu sebanyak 17 temuan, 
kata kau 5 temuan, enklitik dan kata bapak sebanyak 2 temuan. Temuan pronomina persona kedua jamak berupa kata kalian sebanyak 2 temuan.

Pronomina persona ketiga merupakan pronomina yang mengacu kepada seseorang di luar pembicaraan atau yang sedang dibicarakan selaku orang ketiga. Terakhir, temuan pronomina persona ketiga tunggal meliputi kata dia sebanyak 25 temuan, kata ia sebanyak 10 temuan, dan enklitik -nya sebanyak 16 temuan. Temuan pronomina persona ketiga jamak yaitu kata mereka berjumlah 8 temuan.

Berikut analisis penggunaan pronomina persona.

a. Sepulang sekolah Nissa mengajakku untuk bermain di rumahnya. (Suara Aneh dari Barbie, Ayudiah Putri Ramaddani)

Pada kalimat di atas terdapat pronomina persona pertama tunggal yang ditandai dengan enklitik $-k u$ dan pronomina persona ketiga tunggal yang ditandai dengan enklitik -nya. Enklitik - ku merupakan kata ganti untuk penulis karangan dan enklitik -nya merujuk pada tokoh Nissa.

b. Pada suatu hari ada anak bernama Bemby. Dia berjalan setelah pulang sekolah ke arah rumahnya.

(Sepatu Bola Ajaib, Bemby Putra P.)

Pada kalimat di atas terdapat pronomina persona ketiga tunggal yakni dia dan enklitik -nya. Kata dia dan enklitik -nya menggantikan tokoh yang bernama Bemby.

\section{2) Penggunaan Pronomina Demonstrativa}

Pronomina demostrativa merupakan pronomina yang menunjuk sebuah kata benda berupa penunjuk umum, penunjuk tempat, dan penunjuk ihwal. Penggunaan pronomina demonstrativa pada karangan siswa ini merupakan 
jumlah temuan terbanyak kedua, yakni 183 temuan. Data pronomina tersebut terbagi menjadi 155 temuan kata itu, 17 temuan kata ini, 8 temuan kata sana, 1 temuan kata sini, 1 temuan kata situ, dan 1 temuan kata begini. Selain itu, penulis tidak menemukan pronomina penunjuk ihwal berupa kata begitu.

Berikut analisis penggunaan pronomina demonstrativa.

a. Pada setiap malam aku selalu terganggu oleh boneka sapiku. Boneka itu sudah ada sejak aku masih kecil.

(Boneka Hidup Baik Hati, Keira Najla Nurfathiya)

Berdasarkan teori Chaer, pada kutipan di atas terdapat pronomina demonstrativa yang menunjuk dan menggantikan nomina yang jauh dari pembaca atau penulis. Kata itu menunjuk kepada boneka sapi milik tokoh aku.

b. "Saya sedang mencari sepatu antik yang ada di sini tadi sore" kata yang punya sepatu.

(Kisah Sepatu Super, Arief Firmansyah)

Tokoh Arief dan sahabatnya, Ramzy, menemukan sebuah sepatu di trotoar saat pulang sekolah. Dengan demikian, pronomina demonstrativa sini yang terdapat pada kutipan di atas mengacu kepada trotoar tempat sepatu itu ditemukan sekaligus tempat sang pemilik sepatu berada ketika berujar.

\section{3) Penggunaan Pronomina Introgativa}

Pronomina introgativa adalah pronomina yang digunakan untuk menanyakan sesuatu, baik itu orang, tempat, waktu, dan lain-lain. Penggunaan pronomina introgativa pada karangan siswa ini hanya berjumlah 26 temuan. Temuan tersebut terbagi menjadi 6 temuan kata apakah, 5 temuan kata kenapa, 3 temuan kata di mana, 7 temuan kata apa, 2 temuan kata ke mana, 1 temuan kata siapa, 1 temuan kata gimana, dan 1 temuan kata bagaimana. Penulis tidak menemukan bentuk kata tanya waktu berupa kata kapan.

Berikut penggunaan pronomina introgativa. 
a. Tiba2 ada yang berbicara "tunggu sebentar jangan tidur," kata boneka tersebut. Kataku, "hah siapa yang berbicara itu?"

(Bonekaku Temanku, Azkiya Dzikrillah)

Pronomina introgativa ialah kata ganti yang digunakan untuk bertanya atau menanyakan suatu nomina atau yang dianggap konstruksi nominal. Pada kutipan di atas terdapat pronomina introgativa yaitu siapa yang mengacu pada boneka hidup.

b. "Nad, nanti temaniku beli guling ya" kata Natasya.

"Ya" kataku

“Dimana ya?” kata Natasya.

“Hm.. kalo diujung jalan komplek kita gimana?" kataku.

(Misteri Guling Pengganggu, Nada Lafia R.)

Pronomina introgativa yang terdapat pada kutipan di atas ialah kata $d i$ mana dan gimana sebagai bentuk tidak baku dari kata bagaimana. Kata tanya di mana menanyakan tempat tokoh akan membeli guling, sedangkan kata gimana menanyakan persetujuan tokoh Natasya.

\section{4) Penggunaan Pronomina Tidak Tentu}

Pronomina tidak tentu adalah kata-kata yang digunakan untuk menggantikan nomina yang tidak tentu. Penggunaan pronomina ini dalam karangan cerita fantasi siswa berjumlah 29 temuan. Temuan tersebut terdiri atas kata suatu sebanyak 18 temuan, kata masing-masing sebanyak 2 temuan, kata seseorang sebanyak 6 temuan, kata sewaktu sebanyak 2 temuan, dan kata sesuatu sebanyak 1 temuan.

Berikut analisis penggunaan pronomina tidak tentu.

a. Ternyata bapak itu adalah mantan pemain bola karna ia udah pensiun sepatu itupun dikasih pada seseorang karna ia percaya bahwa orang itu bisa menjaganya. 
(Sepatu Bola Ajaib, Bemby Putra P.)

Pada kalimat di atas terdapat pronomina tidak tentu yakni seseorang. Kata seseorang pada kutipan tersebut tidak mengacu pada satu orang yang pasti maka kata tersebut termasuk ke dalam kategori pronomina tidak tentu.

b. Pada suatu hari dia berjalan-jalan, dan dia melihat kakek tua kesulitan menyeberang.

(Sweater Misterius, Stepanus I.H.)

Pada kalimat di atas terdapat pronomina tidak tentu yakni suatu. Kata suatu pada kutipan tersebut tidak mengacu pada satu waktu yang pasti maka kata tersebut termasuk ke dalam kategori pronomina tidak tentu.

Berdasarkan analisis pada hasil, disampaikan bahwa pronomina persona cenderung lebih banyak digunakan dibanding pronomina lainnya dalam karangan cerita fantasi siswa kelas VII SMP Harjamukti Depok. Pada dasarnya, semua jenis pronomina sangat berperan untuk mengembangkan sebuah karangan. Pronomina merupakan kata ganti yang menggantikan posisi suatu nomina. Hal tersebut perlu dilakukan agar karangan yang dibuat tidak mengandung pengulanganpengulangan yang tidak perlu dan menjadi tidak efektif atau tidak enak dibaca. Meski begitu, penggunaan jenis pronomina yang dominan bergantung pada jenis teks atau karangan yang dibuat, penelitian ini membahas pronomina dalam cerita fantasi karangan siswa.

Cerita fantasi menurut Nurgiyantoro (2018: 295) ialah cerita tentang tokoh, alur, latar, tema, dan segala unsur-unsur di dalamnya yang diragukan kebenarannya, baik yang berkaitan dengan seluruh atau sebagian cerita. Ia juga menyatakan bahwa sebagian atau bagian-bagian tertentu dalam cerita fantasi merupakan hal-hal yang masuk akal dan logis, hanya saja dicampuradukkan dengan sesuatu yang masuk akal. Namun, keseluruhan pengembangan cerita tetap 
dikembangkan menggunakan aturan sebab-akibat dan kronologis sehingga dapat dipertanggungjawabkan secara intrinsik.

Sebagaimana yang telah dikemukakan Nurgiyantoro sebelumnya, cerita fantasi menampilkan tokoh sebagai salah satu unsur intrinsik. Artinya, tokoh menjadi salah satu unsur yang sangat penting dalam membangun sebuah cerita fantasi. Cerita fantasi tidak akan berkembang apabila tidak memiliki tokoh yang menjadi pusat dunia di dalamnya. Oleh sebab itu, pronomina persona sebagai kata ganti yang menggantikan orang sebagai nomina sangat diperlukan supaya terhindar dari pengulangan nama diri atau tokoh.

Selain itu, juga terdapat jenis pronomina lain yang digunakan dalam karangan cerita fantasi. Jenis-jenis tersebut adalah pronomina demonstrativa, pronomina introgativa, dan pronomina tidak tentu. Pronomina demonstrativa ialah pronomina penunjuk yang menggantikan posisi suatu benda dalam cerita, latarlatar tempat dalam cerita, atau peristiwa-peristiwa tertentu yang terjadi di dalamnya yang tidak kalah penting dengan keberadaan tokoh sebagai pembangun cerita fantasi.

Selanjutnya, pronomina introgativa, yaitu pronomina yang digunakan dalam bentuk kata tanya. Dalam karangan cerita fantasi karya siswa kelas VII SMP Harjamukti Depok, pronomina jenis ini rata-rata dipakai dalam dialog antartokoh. Tokoh satu dan tokoh lainnya tentu akan terlibat pembicaraan yang mengandung pertanyaan-pertanyaan. Pada kalimat-kalimat pertanyaan itulah pronomina introgativa berperan. Jenis yang terakhir ialah pronomina tidak tentu, yakni pronomina yang menggantikan kata benda yang tidak mengacu pada suatu nomina tertentu.

Penelitian ini melengkapi kajian pronominal yang telah dilakukan sebelumnya. Dalam penelitian sebelumnya, Widiyawati (2016) dengan objek penelitian tajuk rencana surat kabar harian kompas memfokuskan penelitiannya pada pronomina persona yang terdapat di dalamnya. Hasil penelitian tersebut berfokus pada jenis-jenis dari pronomina persona mulai dari pronomina persona pertama, kedua, dan ketiga baik dalam bentuk tunggal maupun jamak. Penelitian 
selanjutnya, Octavia (2018) juga memfokuskan penelitian pada pronomina persona dalam karangan deskripsi siswa.

Penelitian ini memiliki keterkaitan dengan dua penelitian sebelumnya, yakni membahas pronominal. Keterkaitan tersebut juga berupa objek kajian yang menggunakan karangan siswa sebagai data utama. Namun, peneliti memfokuskan penelitian pada lingkup yang lebih luas, bukan hanya pronomina persona, tetapi juga pronomina demonstrativa, introgativa, dan tidak tentu yang berdasarkan teori Chaer. Dengan demikian, kebaruan dari penelitian ini mencakup dari pembahasan yang sudah ada dalam dua penelitian sebelumnya, serta objek yang berbeda.

\section{Simpulan}

Berdasarkan hasil dan pembahasan penelitian, dapat disimpulkan bahwa penggunaan pronomina persona atau kata ganti orang pada karangan cerita fantasi siswa kelas VII SMP Harjamukti Depok lebih dominan dibandingkan dengan jenis pronomina lainnya. Hal tersebut disebabkan pronomina persona berpotensi untuk mengembangkan karangan, khususnya karangan cerita fantasi yang isinya menarasikan kehidupan manusia sebagai tokoh yang berperan di dalam cerita.

\section{Daftar Pustaka}

Alwi, H., dkk. (2014). Tata bahasa baku bahasa Indonesia. Jakarta: Balai Pustaka.

Chaer, A. (2015). Morfologi bahasa Indonesia. Jakarta: Rineka Cipta.

Diakses pada tanggal 5 Desember dari https://books.google.co.id/books?id= ZtjDwAAQBAJ\&pg=PA295\&dq=c erita+fantasi+adalah\&hl=id\&sa=X\&ved=0ahUKEwibi5 6nufmAhUIfX0 KHdJvAFMQ6AEIMDAB\#v=onepage $\& q=$ cerita\%20fantasi\%20adalah\&f $=$ false

Muslich, M. (2014). Garis-garis besar tata bahasa baku bahasa Indonesia. Bandung: Refika Aditama.

Nurgiyantoro, B. (2018). Sastra anak. Yogyakarta: Gajah Mada University Press. Obor Indonesia. 
Octavia, S. (2018). Penggunaan Pronomina Persona dalam Karangan Deskripsi Siswa Kelas VII MTs Negeri 13 Jakarta Tahun Pelajaran 2018/2019. (Skripsi). Fakultas Ilmu Tarbiyah dan Keguruan. Universitas Islam Negeri Syarif Hidayatullah. Diakses pada tanggal 1 Desember dari http://repository.uinjkt.ac.id/dspace/handle/123456789/43187

Rahardi, K. (2009). Bahasa Indonesia untuk perguruan tinggi. Jakarta: Erlangga. Sarumpaet, Toha-R.K. (2017). Pedoman penelitian sastra anak. Jakarta: Pustaka Sugiyono. (2016). Metode penelitian kuantitatif, kualitatif, dan R\&D. Bandung: Alfabeta.

Widiyawati, T. (2016). Pronomina pada Tajuk Rencana Surat Kabar Harian Kompas. (Skripsi). Fakultas Bahasa dan Sastra Indonesia. Universitas Indraprasta PGRI. 